\title{
ERRATUM
}

\section{Meta-analysis of genome-wide association studies of anxiety disorders}

T Otowa, K Hek, M Lee, EM Byrne, SS Mirza, MG Nivard, T Bigdeli, SH Aggen, D Adkins, A Wolen, A Fanous, MC Keller, E Castelao, Z Kutalik, SV der Auwera, G Homuth, M Nauck, A Teumer, Y Milaneschi, J-J Hottenga, N Direk, A Hofman, A Uitterlinden, CL Mulder, AK Henders, SE Medland, S Gordon, AC Heath, PAF Madden, ML Pergadia, PJ van der Most, IM Nolte, FVA van Oort, CA Hartman, AJ Oldehinkel, M Preisig, HJ Grabe, CM Middeldorp, BWJH Penninx, D Boomsma, NG Martin, G Montgomery, BS Maher,

EJ van den Oord, NR Wray, H Tiemeier and JM Hettema

Molecular Psychiatry (2016) 21, 1485; doi:10.1038/mp.2016.11; published online 9 February 2016

Correction to: Molecular Psychiatry (2015); advance online publication 12 January 2016; doi:10.1038/mp.2015.197
Following publication of the above article, the authors noticed that the fifteenth author's name was presented incorrectly. The author's name should have appeared as S Van der Auwera. The publisher regrets the error. 